\title{
Postharvest Loss and Mycofloral Association in Some Culinary Mushrooms in Kathmandu City, Nepal
}

\author{
Hari Sharan Adhikari ${ }^{1^{*}}$, Sanjay Kumar Jha \\ 1Department of Botany, Amrit Campus, Thamel, Kathmandu, Nepal \\ 2 Central Department of Botany, Tribhuvan University, Kathmandu, Nepal \\ *Corresponding author: aharisharan@gmail.com
}

(Received: 22 April, 2020, Received in revised form: 2 August, 2020, Accepted:10 August,2020, Available online)

\section{Highlights}

- Substantial losses were found in the postharvest stage of mushroom. Various factors are associated in such loss of mushroom but mycoflora have the important role for the deterioration of the stuff.

- Mushrooms samples were collected from three major vegetable market of Kathmandu Valley for the detection of microbial contaminants.

- A total of 21 fungal species were identified as contaminant from theses mushroom samples which were the major cause of the postharvest loss in cultivated mushrooms.

\begin{abstract}
Postharvest deterioration of perishable crop is one of the major constrains in food supply. Similar instances are also prevalent in mushrooms. Contamination by fungal pathogens, occurrence of mycotoxins in these goods pose serious health issue. As such, evaluation of mycofloral contamination on commonly grown mushroom namely; Pleurotus sp and Agaricus sp. were made with focus on reducing its postharvest loss. Questionnaire survey to the mushroom growers and mushroom seller of Kathmandu valley was carried out to evaluate the post-harvest losses, causes and management procedure followed by them. Postharvest loss in Agaricus bisporus was higher than in Pleurotus sp., caused by microbial contaminants where extensive use of synthetic fungicides was found. Samples (i.e., Agaricus bisporus, Pleurotus ostreatus and Pleurotus florida) were collected from three major vegetable market of Kathmandu city to detect the mycoflora associated with postharvest deterioration. A total of 21 fungal species belonging to 10 genera were isolated from the samples. The most frequent fungal contaminants were Aspergillus niger (57.77\%), Rhizopus sp (42.22\%), Trichoderma viride (34.44\%) and Aspergillus flavus (27.77\%). As the mushrooms appeared prevailed with many fungal contaminants, more caution should be taken such as selection of strain from resistant varieties, proper sanitation during in-field and postharvest conditions.
\end{abstract}

Key Words: Oyster Mushrooms, White button Mushroom, Fungal contaminants, Postharvest loss

\section{Introduction}

The use of mushroom as food is probably as old as human civilization, the reference of which was found in Vedas too. Now it has been widely used as foods. It is estimated that about 1500-2000 edible mushroom species exist in the world of which only 981 species have been identified. Among these, 92 species have been domesticated and about 60 species of these are

${ }^{*}$ Corresponding author 
commercially cultivated (Mau et al. 2004). Nearly 20 species of these mushroom are cultivated on an industrial scale (Yeung, 2004) and only 12 species such as Agaricus sp, Pleurotus spp., Flammulina velutipes, Ganoderma lucidum, Grifola frondosa, Auricularia spp., Lentinula edodes, Volvariella spp, Morchella esculenta etc. are cultivated in great concentration (Barros et al. 2016). Cultivation of edible mushroom has been massively increased throughout the world. In the context of Nepal, cultivation and consumption of mushrooms is being popular in recent days. Among the common cultivated mushrooms (i.e., Pleurotus sp, Agaricus bisporus, Volvariella volvacea, Lentinus sp and Ganoderma lucidum), Oyster mushroom (Pluerotus spp) and White button mushroom (Agaricus spp) are the most popular mushroom grown in Nepal (Parajuli, 2014) because, it can simply grow in wide range of temperature (Yang et al. 2013) and easy availability of raw material required for this.

Mushrooms, being fungi, are heterotrophic in nature and also one of the perishable crops, therefore stakeholders are facing many difficulties in mushroom business. This contributes to in-field and postharvest losses and serve as a constraint on transportation and marketing of fresh mushrooms (Rai \& Arumuganathan, 2008; Xiao et al. 2011). Microbial contamination is the major cause of food spoilage. It does not only result great economic losses (in-field and postharvest loss), but also affects human and animal health through the mycotoxin synthesis (Pitt \& Hocking, 1997; Tutelyan, 2004). A number of harmful fungi affect the quality and quantity of mushroom from cultivation to kitchen. Many of these acts as competitor moulds thereby adversely affecting spawn run whereas others attack the fruit bodies during cultivation and postharvest stages. Various competitor moulds and pathogenic fungi such as Mycogone perniciosa, Verticillium fungicola, Cladobotryum dendroides, Trichothecium roseum, Fusarium sp, Scopulariopsis fimicola, Papulospora byssina, Sporendonema purpurescens, Diehliomyces microsporus, Peziza ostracoderma, Chaetomium olivaceum, Coprinus spp., Trichoderma spp., Aspergillus spp., Penicillium spp., Mucor spp., Rhizopus spp., Sporotrichum sp., Sepedonium sp., Cephalosporium spp., Gliocaldium spp., Alternaria spp., Papulospora spp. etc. are mostly prevalent in substrate and postharvest contamination (Adhikari and Jha, 2017; Biswas, 2014). These fungi causing contamination produces mycotoxins that have no biochemical significance in fungal growth and development (Dinis et al. 2007), however many mycotoxins in food are nephrotoxic, hepatotoxic, immunosuppressive, or carcinogenic (Ostry \& Ruprich, 1998).

Unfortunately, like all other crops, different biotic and abiotic agents/factors during mushroom cultivation and postharvest conditions also affects it adversely. Among the causes of the loss in mushroom, microbial contamination is one of the major factors that results the economic loss (Biswas, 2014). However, a comprehensive investigation of the loss of mushrooms cultivated in Nepal and their causes is lacking. The objective of this study was therefore to evaluate the postharvest loss in culinary mushroom and explore the microbial contaminants responsible for it.

\section{Materials and Methods}

\section{Evaluation of in-field and postharvest loss}

A questionnaire survey was conducted in field condition and Market level. In field condition it was conducted with 30 respondents in different cultivation area i.e., Balambu, Tokha, Kirtipur, Dhapakhel, Shatungal, Gurjudhara, in Kathmandu Valley. In Market level it was conducted with 50 respondents in the four major vegetable market i.e., Kalimati, Tukucha, Balaju and Balkhu in Kathmandu Valley. The survey was focused on the postharvest losses in mushrooms, their causes and management practices. The in-field and postharvest loss of mushroom were evaluated on the basis of respondent's perception and experience.

\section{Collection of mushroom samples}

Mushrooms samples of Agaricus bisporus, Pleurotus ostreatus and Pleurotus florida, were collected from the three major vegetable market (i.e., Kalimati Tarkari Bazar, Tukucha Tarkari Bazar and Machhapokhari Tarkari Bazar, Balaju) of Kathmandu Valley. Samples were collected in the sterilized plastic bags and taken to Plant Pathology and Bacteriology Unit, Central Department of Botany, Tribhuvan University, Kirtipur, Kathmandu for the further experiments.

\section{Isolation and identification of microbial contaminants}

The surface of sample wascut into $3 \mathrm{~mm}$ sized pieces and plated into Potato Dextrose Agar (PDA) plates. The pieces were cut from the top (pileus), middle (stipe) and bottom (base) portion of the mushroom samples to make the uniformity in sampling. A 
total of 90 plates ( 10 replicates for sample of each species from each market) were incubated at $25 \pm 1{ }^{\circ} \mathrm{C}$ for 10 days. Pure cultures of fungi were prepared by transferring single hyphal tip of the fungus from group of mixed colonies to the PDA plates (Aneja, 2003). All the pure cultures were kept in refrigerator at $4^{\circ} \mathrm{C}$ for preservation. One week later, the microbial contaminants were identified using standard literature (Barnett \& Hunter, 2003; Watanabe, 2010).

\section{Data analysis}

All the data like mushroom production and loss from field and data like occurrence of fungal contaminants species from laboratory were entered in MS Excel 2016 and analyzed to determine mean and frequency. Frequency rank curve was prepared for the comparison of frequency occurrence of various fungal contaminants reported from different mushroom samples.

\section{Results and Discussion}

\section{Production ioss of mushrooms (in-field and postharvest)}

Cultivation and consumption of oyster mushroom was found significantly higher than that of the button mushrooms. According to respondents involved in survey, the production loss of button mushroom (44.40\%) was higher in comparison to oyster mushroom (37.20\%) in both in-field and postharvest conditions (Fig.1). The high production loss in mushroom could be the consequence of high moisture content of mushrooms, which rapidly lose water and are easily attacked by microbes and subsequently leads to deterioration (Ares et al. 2007). Due to complex cultivation technique, proper sanitation may not be maintained which can be the cause of more loss in Button mushroom than in Oyster mushroom.

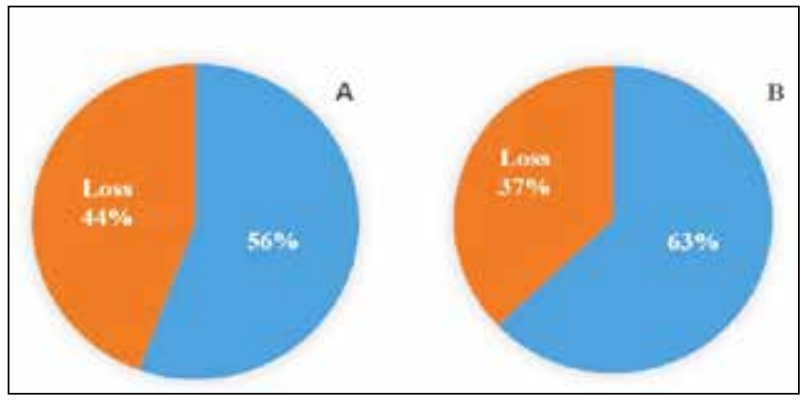

Fig. 1: Status of Postharvest loss in Mushrooms (A: White button and B: Oyster)

\section{Causes and management practice of production loss}

In the postharvest loss of mushroom, the occurrence of the fungi and bacteria was evident in case of both Pleurotus sp and Agaricus sp. The percentage of loss caused by insect was lower and negligible amount of mushroom was lost due to other reasons such as mechanical damages caused during transportation and mishandling etc. So, fungi and bacteria were most severe to cause the postharvest loss in both type of mushroom based on the respondent's observations (Fig. 2).

The occurrence of these organisms i.e. fungi,

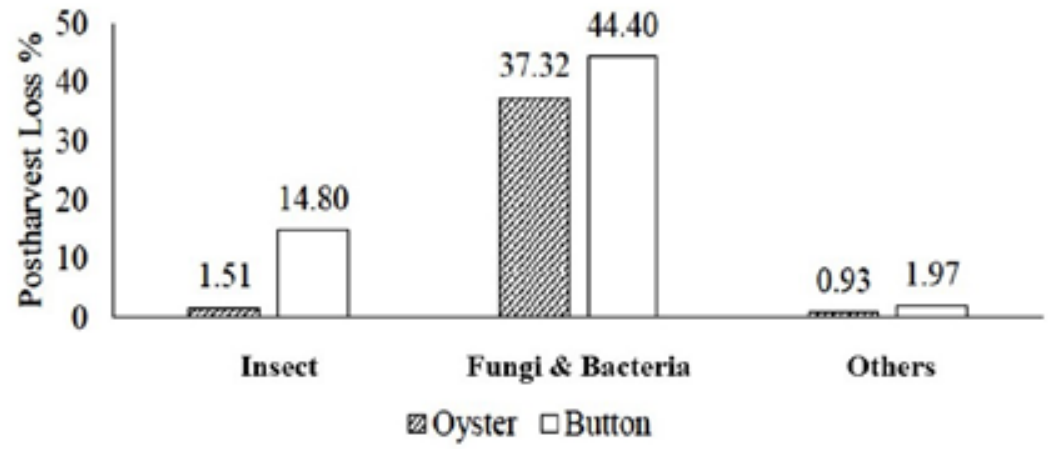

Fig. 2: Production loss in mushroom due to different causes. bacteria and insect were different with seasonal variation. Their occurrence was higher in summer season which was followed by rainy, spring and winter season (Fig. 3). According to respondents, no occurrence of insect was reported in winter season and also least occurrence of fungi/bacteria. Comparing the occurrence of fungi/bacteria and insects within the season, there was substantial difference. The occurrence percentage of fungi/bacteria was higher than that of insects in all seasons. This could be the influence of nature of water activity in mushroom where the high-water activity of fresh mushroom can provide ideal environment for microbial growth (Olotu et al. 2015) 


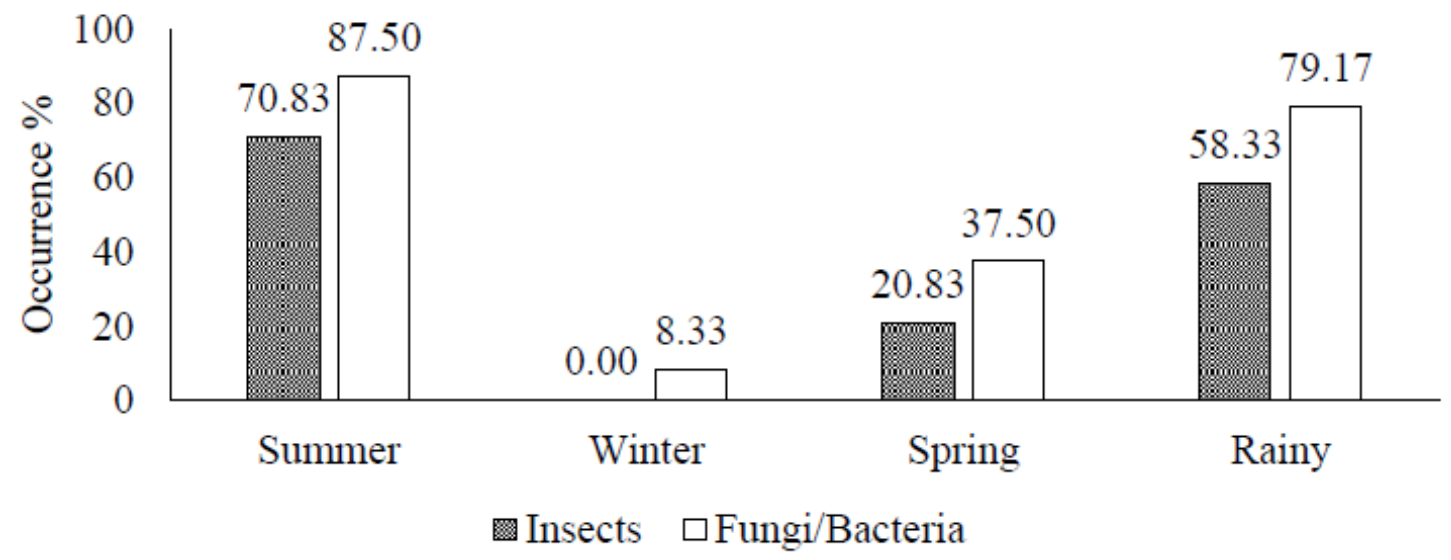

Fig. 3: Occurrence of insects and fungi/bacteria causing production loss in mushroom with seasonal variation.

Major method using for the management of postharvest loss in mushroom of each type was use of synthetic fungicides (95.45\%) such as Nuvan, Bavistin DF and Dicholrophus 76 EC, Mancozeb and Carbendazim. Among all respondents, $63.64 \%$ of respondents stated that they are using both synthetic fungicides and biological methods to manage in-field and postharvest loss of mushroom. Use of others (18.18\%) such as mechanical methods were also reported (Fig. 4). In the field survey, it was observed that farmers use Neem (Azadirachta indica) oil to eradicate the fungal/bacterial contaminations. Spray of the petroleum product (e.g, grease, diesel etc.) on the plastic wall of the cultivation tunnel and use of the net in the ventilation was the practice done to avoid the mushroom pests. Use of the synthetic fungicides have recommended by Kosanovic et al. (2015) but retention of such chemicals in food may cause the adverse effect on consumers' health (Palmer et al. 2013).

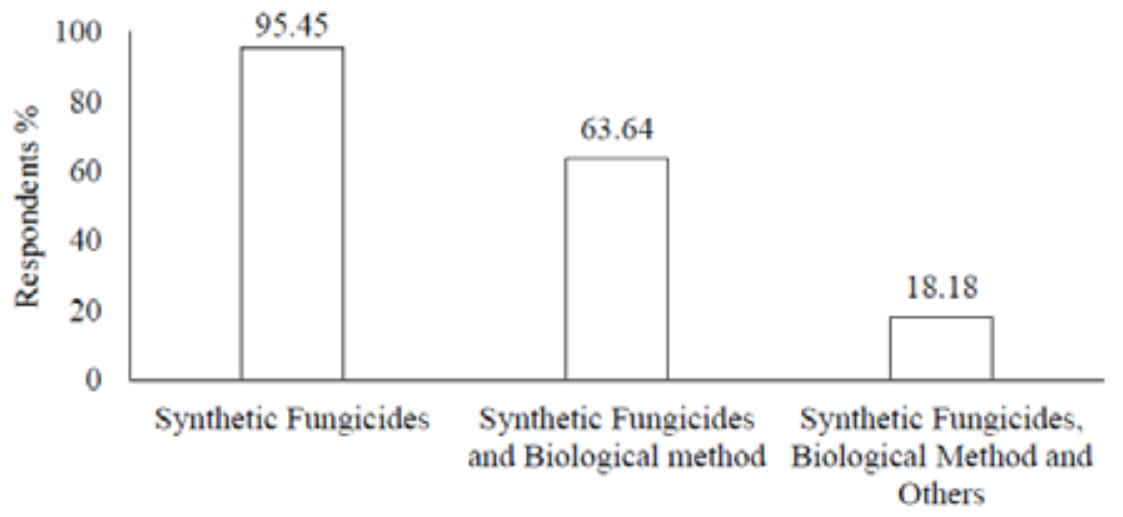

Fig. 4: Control measures practiced for the management of postharvest loss in mushrooms.

\section{Detection of microbial contaminants}

A total of 21 fungal species belonging to 10 genera were found to be growing on petri-plates in three different types of mushrooms such as Agaricus bisporus, Pleurotus ostreatus and Pleurotus florida (Figure. 6). Among the mushroom type, the highest number of fungal contaminants was found in A. bisporus followed by Pleurotus florida and Pleurotus ostreatus (Table 1). Most of the fungal contaminants was from Ascomycota (17 species) and few from Zygomycota (2 species) in which many of them are common to all mushroom type.

Table 1: Number of fungal contaminants in different mushroom types.

\begin{tabular}{|l|c|}
\hline \multicolumn{1}{|c|}{ Mushroom type } & Number of Microbial contaminants \\
\hline Pleurotus ostreatus & 14 \\
\hline Pleurotus florida & 15 \\
\hline Agaricus bisporus & 19 \\
\hline
\end{tabular}


Most frequent species in P. ostreatus was Aspergillus niger followed by Rhizopus sp, Trichoderma viride and Aspergillus fumigatus (Figure: 5, A). Three species of Chaetomium, Alternaria alternata and a species of Penicillium, Mucor sp, Aspergillus flavus, Aspergillus brevipes, Gliocladium sp. and Fusarium oxysporum were also prevailed species in Pleurotus ostreatus. In Pleurotus florida, also Aspergillus niger was most frequent which was followed by Trichoderma viride, Aspergillus brevipes, Aspergillus flavus, Rhizopus sp. (Figure:5, B). Meanwhile Aspergillus fumigatus, Gliocladium sp Penicillium sp, Aspergillus sp, Geotrichum sp, Chaetomium spirale, Mucor sp, Fusarium oxysporium and Rhizopus sp were less frequent species in this mushroom type with two unidentified species of fungi. This is comparable to the result of Adhikari \& Jha (2017) where the moulds like Aspergillus niger, Rhizopus sp, Trichoderma viride, Aspergillus flavus, Aspergillus brevipes, Gliocladium sp etc. was isolated from Oyster mushrooms.
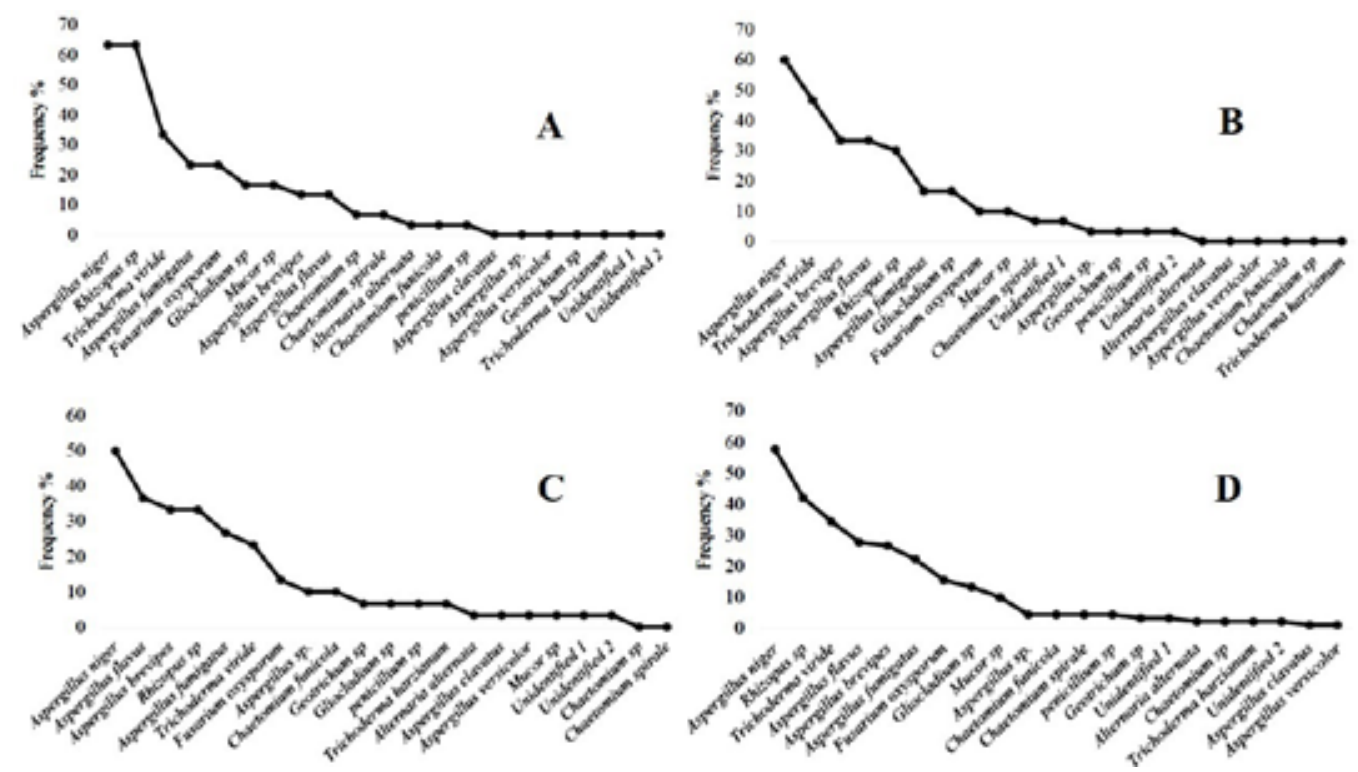

Fig5: Frequency rank curve of microbial contaminants reported in Mushrooms (A: P. ostreatus, B: P. florida. C: A. bisporus and D: All mushroom type)

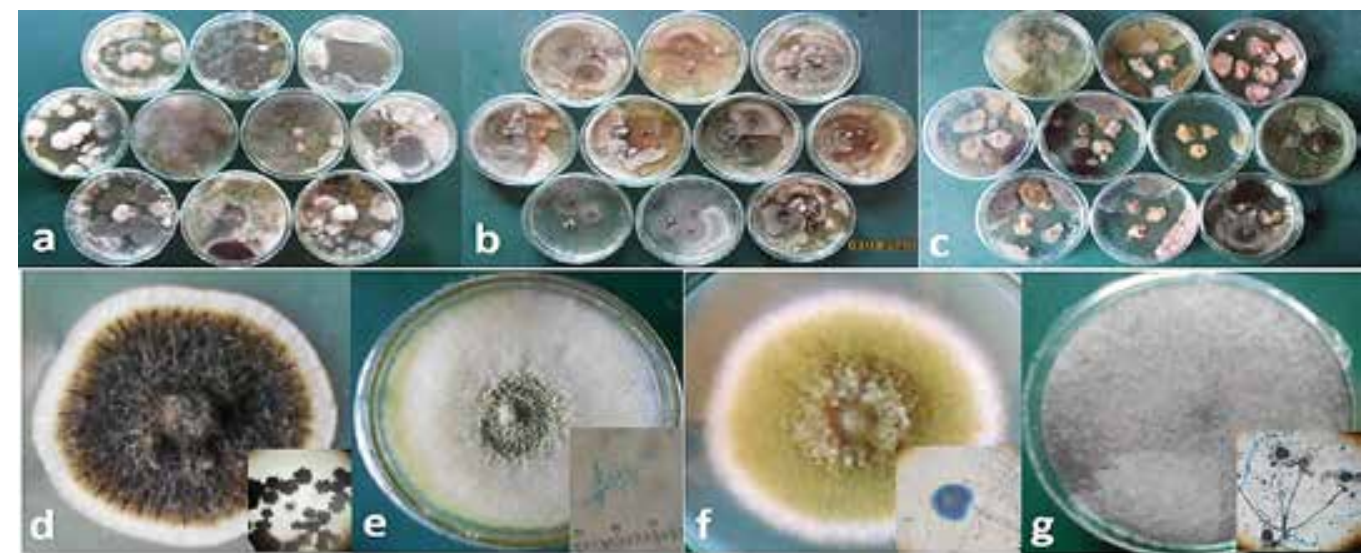

Fig. 6: Fungal growth in petriplates (a: P. ostreatus, b: P. florida and c: A. bisporus) and pure fungal colony with microscopic view (d: A. niger, $e:$ T. viride, $f:$ A. flavus and Rhizopus sp)

Aspergillus niger was the most frequent species in Agaricus bisporus too, which was followed by Aspergillus flavus, Aspergillus brevipes and Rhizopus sp (Figure: 5, C). In Agaricus bisporus, four species of Aspergillus sp and Mucor sp, Penicillium sp, Rhizopus sp, Alternaria alternata, Chaetomium funicola, Geotrichum sp, Trichoderma harzianum, Gliocladium $s p$, Fusarium oxysporum and two unidentified species were found to be less frequent. The frequency rank curve (Figure 5, D) revealed that the most frequent fugal species of all the mushroom types studied and it was A. niger (57.77\%) and was followed by Rhizopus sp, Trichoderma viride and Aspergillus flavus with the frequency value $42.22 \%, 34.44 \%$ and $27.77 \%$ respectively. 
The sources of these mycofloral association on mushroom might be the contaminated substrate used for cultivation, as reported by Dandge (2012), Kouser et al. (2013) and Prameela \& Devi (2016). Occurrence of such fungal contaminants were also reported by Biswas et. al. (2012) and Biswas (2014) on mushrooms while Chun et al. (2012) and Suada et al. (2015) encountered similar fungal population in the air of cultivation area of oyster mushrooms. So, it can be argued that these contaminants could be concomitant contamination playing the vital role in the loss of mushroom. According to Bellettini et al. (2018) cultivation of edible mushrooms can often be affected by many mycofloral contaminants causing high production loss and these infections are facilitated by the specific conditions like warm temperatures, high humidity and a low aeration rate, under which the mushroom cultivation is commonly carried out.

\section{Conclusions}

The postharvest loss is substantial in all commonly grown mushroom, especially higher in Agaricus bisporus. The major cause of the postharvest loss is microbial contamination. Among twenty-one fungal contaminants, Aspergillus niger, Rhizopus sp, Trichoderma viride and Aspergillus flavus were the most prevalent. Possible measures such as biological control and mechanical methods must be applied instead of synthetic fungicides to minimize the occurrence of microbial contaminants. Extensive study is essential to assess the conditions of postharvest loss in commonly grown mushroom in Nepal.

\section{Acknowledgements}

Authors are grateful to Prof. Dr. Mohan Siwakoti, Head of Central Department of Botany, TU for providing laboratory facilities and Prof. Dr. Mukesh Kumar Chettri for encouraging to prepare the manuscript. We also would like to acknowledge thanks to Mr. Sujan Balami and Mr. Bhawani Bhandari for their help during field work, and the informant i.e. the local mushroom stakeholders of Kathmandu valley, for their valuable information.

\section{References}

Adhikari, H.S. and Jha, S.K. 2017. Postharvest microbial contamination in oyster mushroom and their management using plant Essential oils. Bio Bulletin, 3(1): 104-108

Aneja, K. R. 2003. Experiments in microbiology, plant pathology and biotechnology. New Age International.

Ares, G., Lareo, C. and Lema, P. 2007. Modified atmosphere packaging for postharvest storage of mushrooms. A review. Fresh Produce, 1(1): 32-40.

Barnett, H.L. and Hunter. B.B. 2003. Illustrated genera of Imperfect fungi. 4th ed. Burgess Publishing Company, Minneapolis 15 , Minneapolis.

Barros, A. B., Bell, V., Ferrão, J., Calabrese, V., \& Fernandes, T. H. 2016. Mushroom Biomass: Some Clinical Implications of $\beta$-Glucans and Enzymes. Current Research in Nutrition and Food Science Journal, 4(Special Issue Nutrition in Conference October 2016), 37-47.

Bellettini, M. B., Bellettini, S., Fiorda, F. A., Pedro, A. C., Bach, F., Fabela-Morón, M. F., \& Hoffmann-Ribani, R. 2018. Diseases and pests noxious to Pleurotus spp. mushroom crops. Revista Argentina de microbiologia, 50(2), 216-226.

Biswas, S., Datta, M. and Ngachan, S.V. 2012. Mushrooms: A Manual for cultivation. New Delhi, Pp. 100-126.

Biswas, M.K. 2014. Microbial contaminants in Oyster mushroom (Pleurotus Ostreatus) Cultivation their Management and Role of Meterological Factors. In Proceedings of 8th International Conference on Mushroom Biology and Mushroom Products (ICMBMP8), New Delhi, India, 19-22 November 2014. Volume I \& II (pp. 567-575). ICAR-Directorate of Mushroom Research.

Chun, S.C., Ahn, Y.N., Khan, S.M., Chung, I.M., Won, H.Y., Jhune, C.S. and Park, Y.J. 2012. The microbial population in the air of cultivation facility of oyster mushrooms. Journal of Microbiology, 50(6): 1053-1057. 
Dandge, V.S. 2012. Studies on some fungi in button mushroom cultivated in Akola (Amanatpur). Recent Research in Science and Technology, 4(10).

Dinis, A.M.P., Lino, C.M. and Pena, A.S. 2007. Ochratoxin A in nephropathic patients from two cities of central zone in Portugal. Journal of pharmaceutical and biomedical analysis, 44(2): 553-557.

Kouser, S., Ahmed, M. and Shah, S. 2013. Mushroom Units of Kashmir Valley. Plant Pathology Journal, 12(2): 104-109.

Kosanović, D., Potočnik, I., Vukojević, J., Stajić, M., Rekanović, E., Stepanović, M. and Todorović, B. 2015. Fungicide sensitivity of Trichoderma spp. from Agaricus bisporus farms in Serbia. Journal of Environmental Science and Health, Part B, 50(8): 607-613.

Mau, J.L., Chang, C.N., Huang, S.J. and Chen, C.C. 2004. Antioxidant properties of methanolic extracts from Grifola frondosa, Morchella esculenta and Termitomyces albuminosus mycelia. Food chemistry, 87(1): 111-118.

Olotu, I.O., Obadina, A.O., Sobukola, O.P., Adegunwa, M., Adebowale, A.A., Kajihausa, E., Sanni, L.O., Asagbra, Y., Ashiru, B. and Keith, T. 2015. Effect of chemical preservatives on shelf life of mushroom (Pleurotus ostreatus) cultivated on cassava peels. International Journal of Food Science \& Technology, 50(6): 1477-1483.

Ostrý, V. and Ruprich, J. 1998. Determination of the mycotoxin fumonisins in gluten-free diet (corn-based commodities) in the Czech Republic. Central European journal of public health, 6(1): 57-60.

Palmer, M. J., Moffat, C., Saranzewa, N., Harvey, J., Wright, G. A. and Connolly, C. N. 2013. Cholinergic pesticides cause mushroom body neuronal inactivation in honeybees. Nature Communications, 4(1): 1-8.

Parajuli, G.P. 2014. The Status of Collection and Utilization of Nepalese Mycobiota. In Proceedings of the seminar on mushroom consumption and poisoning risk (Ed. J.K. Raut), Khumaltar, Lalitpur, Nepal, 14 January 2014. (Pp.13-18) Nepal Academy of Science \& Technology.

Pitt, J.I. and Hocking, A.D. 1997. Zygomycetes. In Fungi and food spoilage. Springer, US Pp. 173-201.

Prameela, M. and Devi, G.U. 2016. Occurrence of different mycoflora in oyster mushrooms and their management. International Journal of Tropical Agriculture, 34(4): 943-945.

Rai, R.D. and Arumuganathan, T. 2008. Post harvest technology of mushrooms. National Research Centre for Mushroom, Indian Council of Agricultural Research.

Suada, I.K., Sudarma, I., Kim, B.S., Cha, J.Y. and Ohga, S., 2015. Fungal Contaminant Threaten Oyster Mushroom (Pleurotus ostreatus (Jacq. ex Fr.) Kummer) Cultivation in Bali. Journal of the Faculty of Agriculture, Kyushu University, 60(2): 309313.

Tutelyan, V. A. 2004. Deoxynivalenol in cereals in Russia. Toxicology Letters, 153(1): 173-179.

Watanabe, T. 2010. Pictorial atlas of soil and seed fungi: morphologies of cultured fungi and key to species. CRC press.

Xiao, G., Zhang, M., Shan, L., You, Y. and Salokhe, V. M. 2011. Extension of the shelf-life of fresh oyster mushrooms (Pleurotus ostreatus) by modified atmosphere packaging with chemical treatments. African Journal of Biotechnology, 10(46): 95099517.

Yang, W., Guo, F. and Wan, Z. 2013. Yield and size of oyster mushroom grown on rice/wheat straw basal substrate supplemented with cotton seed hull. Saudi journal of biological sciensces, 20(4): 333-338.

Yeung, W.H., 2004. Chemical and biochemical basis of the potential anti-tumor properties of Ganoderma lucidum. Current Topics in Nutraceutical Research, 2: 67-77. 